\title{
Investigation of Soil and Bearing Capacity in Different Site Conditions
}

\author{
Mr. Umesh N. Waghmare ${ }^{1}$ and Dr. K. A. Patil ${ }^{2}$ \\ ', P. G. Student, Civil Department, Govt. College of Engineering Aurangabad (M.S.) India 431005 \\ 2, Associate Professor, Civil Department, Govt. College of Engineering Aurangabad (M.S.) India 431005,
}

\begin{abstract}
Soil is a loose deposit of minerals and organic particles occupying top position of earth crust. It is naturally available material produced by weathering of the rock. Soil being the product of nature, its properties may vary from site to site. In today's context due to massive increase in population, urbanization and rapid industrialization, there is no option left but to adopt construction on limited available lands like waste disposal site and the sites where water table is nearer to ground. So it is very essential to study geotechnical properties of soil in such typical site conditions and civil engineer must be ready to plan, design, construct structures and maintain them throughout the life of structures. The record of trial pits bore hole and testing of soils collected from different site locations and depths gives necessary input for design of foundations. In the present paper the geotechnical investigations for the proposed construction of "Cantonment fund servant's quarters" and "school building" for Cantonment Board at Aurangabad" is carried out. Based on the study and judicious judgment the depth of foundation is decided.
\end{abstract}

Keywords: Bearing capacity, Depth of foundation

\section{Introduction}

A foundation is a lower part of a structure which transmits load directly into the underlying soil. If the soil below the structure is sufficiently strong and capable of supporting the required load, then shallow foundations can be used. If the soil conditions are weak, then deep foundations are more suitable. Geotechnical engineering is the discipline that works with soil properties to establish the bearing capacity and allowable bearing capacity of footings. Geotechnical engineers are members of design team who provide this information to those responsible for design. Often it is stated that geotechnical engineering is an "art form" rather than a science. Bearing capacity is affected by various factors like type of soil and its properties, change in level of water table, eccentric loads, inclined loads, dimensions of the footings, etc. The decision regarding depth of foundation of a structure and type of foundation is decided based on judicious judgment by an interpretation of subsoil conditions based on an economically reasonable number of explorations. Based on experience and supported by theory, the geotechnical engineer interprets the information in order to predict foundation performance. A number of bearing capacity theories have been presented over the years. Bell introduced theory which is useful to understand the concept of bearing capacity.

Terzaghi in 1943 proposed the first comprehensive bearing capacity analysis for the case of strip footing with rough base for a frictional cohesive soil using limit equilibrium method. The other investigators Prandtl (1920) and Reissner (1924) also contributed in bearing capacity analysis. Prandtl (1920) obtained analytical closed form solutions for ultimate bearing pressure for the case of a strip footing on weightless semiinfinite space. This analysis is applicable to frictional cohesive soil and to a purely cohesive soil. Meyerhoff in 1951 used limit equilibrium method for the evaluation of ultimate bearing capacity of shallow foundation with rough base for a frictional cohesive soil. Many investigators attributed the beneficial changes in properties of soil and increase in the load carrying capacity of the soil by various methods like compaction, preloading, grouting, densification using vibratory equipment, using in situ reinforcement, using geotextiles, chemical stabilizations, etc.

\section{EXPERIMENTAL WORK}

The present work consists of soil investigations for the proposed construction of "Cantonment fund servant's quarters" and "school building" for Cantonment Board at Aurangabad". For this purpose, the soil samples were collected from two sites at different depths and the details of the sites from which soil samples are collected are as shown in the table 1. 
Investigation Of Soil And Bearing Capacity In Different Site Conditions

Table1: Details of Site from Where the Soil Samples Collected

\begin{tabular}{|c|l|c|}
\hline Symbol & \multicolumn{1}{|c|}{ Location } & Depth of foundation in meter \\
\hline Site-A & $\begin{array}{l}\text { Waste disposal site cantonment land } \\
\text { Survey.No.207/1,Aurangabad }\end{array}$ & $1.0,1.5,2.0,2.5$ and 3.0 \\
\hline Site-B & $\begin{array}{l}\text { Behind weekly market, Cantonment land } \\
\text { Survey No 40/1144, Aurangabad }\end{array}$ & $1.0,1.5$ and 1.8 \\
\hline
\end{tabular}

\section{Laboratory Investigation Of Soils For Different Sites}

The aim of this work is to decide the optimum depth of foundation based on systematic laboratory study carried out. For this purpose from the proposed site-A of 'Cantonment fund servant's quarters' for Cantonment Board at Aurangabad representative soil samples from the different depth of foundation i.e. $1.0 \mathrm{~m}$, $1.5 \mathrm{~m}, 2.0 \mathrm{~m}, 2.5 \mathrm{~m}$ and $3.0 \mathrm{~m}$ were collected. Fig. 1 shows soil profile of trial pit taken at site-A.

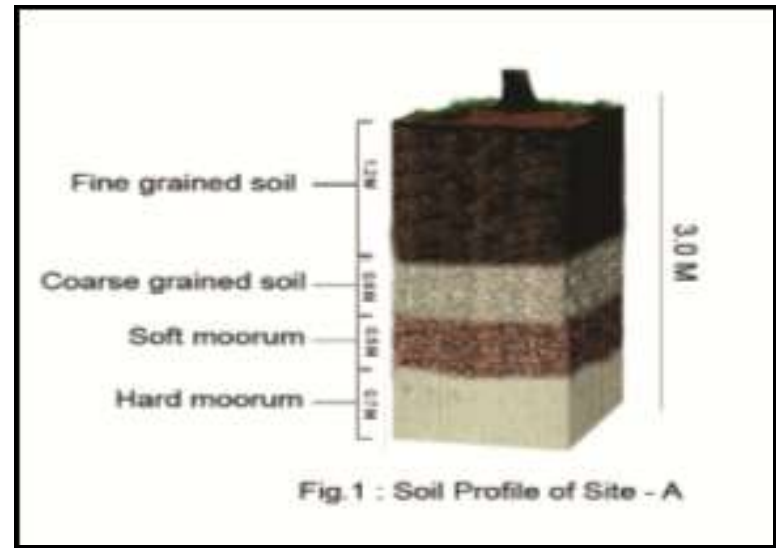

Experimental work was planned to study the properties of different soils collected for determination of ultimate bearing capacity of the soil. For all these soils the standard Proctor test and direct shear tests were conducted to determine maximum dry density, optimum moisture content, cohesion and angle of internal friction (Ø). Similarly the specific gravity of the soil was found out. The test results of different soil samples collected from different sites at varying depths are as shown in table 2 .

Table 2: Geotechnical Properties of Soil Collected from Site-A at Varying Depth

\begin{tabular}{|c|c|c|c|c|c|}
\hline $\begin{array}{c}\text { Depth of } \\
\text { trial pit } \\
\text { in meter }\end{array}$ & $\begin{array}{c}\text { Specific } \\
\text { Gravity }\end{array}$ & $\begin{array}{c}\text { Maximum } \\
\text { Dry density } \\
\text { in gm/cm }\end{array}$ & $\begin{array}{c}\text { Optimum } \\
\text { moisture } \\
\text { content } \%\end{array}$ & $\begin{array}{c}\text { Cohesion in } \\
\mathrm{kN} / \mathrm{m}^{2}\end{array}$ & $\begin{array}{c}\text { Angle of internal } \\
\text { friction (Ø) in } \\
\text { degrees }\end{array}$ \\
\hline 1.0 & 2.54 & 1.45 & 26.40 & 24.0 & 18.0 \\
\hline 1.5 & 2.62 & 1.64 & 18.10 & 13.0 & 27.0 \\
\hline 2.0 & 2.68 & 1.71 & 16.90 & 8.0 & 33.0 \\
\hline 2.5 & 2.73 & 1.75 & 15.10 & 6.0 & 34.0 \\
\hline 3.0 & 2.76 & 1.82 & 14.20 & 4.0 & 36.0 \\
\hline
\end{tabular}

From table 2, it is observed that as depth of foundation increases, specific gravity of soil also increases. For $1.2 \mathrm{~m}$ depth the type of soil found to be clayey soil the maximum dry density is found to be less i.e. 1.45 $\mathrm{gm} / \mathrm{cm}^{3}$ and optimum moisture content is $26.40 \%$. The value of cohesion is found to be $24 \mathrm{kN} / \mathrm{m}^{2}$. The soils at $2.0 \mathrm{~m}$ to $2.5 \mathrm{~m}$ depth are found to be coarse in nature and hence the maximum dry density is found in to be 1.71 and $1.75 \mathrm{gm} / \mathrm{cm}^{3}$ and optimum moisture content found to be $16.90 \%$ to $15.10 \%$ respectively. The cohesion is found to be in the range of 8.0 to $6.0 \mathrm{kN} / \mathrm{m}^{2}$. Soil at $3.0 \mathrm{~m}$ depth is found to be coarser, for which the value of maximum dry density is found to be $1.82 \mathrm{gm} / \mathrm{cm}^{3}$ and optimum moisture content is $14.20 \%$. The cohesion is 4.0 $\mathrm{kN} / \mathrm{m}^{2}$. 
At site- B representative soil samples from the different depth of foundation i.e. $1.0 \mathrm{~m}, 1.5 \mathrm{~m}$, and $1.8 \mathrm{~m}$ were collected for proposed construction of 'School building' for Cantonment Board office at Aurangabad. Fig. 2 shows soil profile of trial pit taken at site-B.

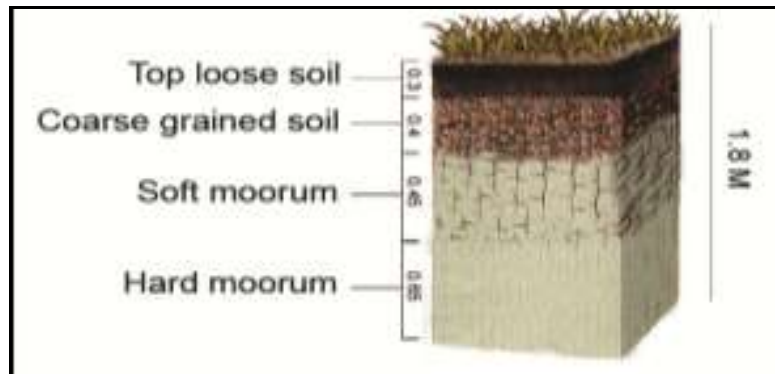

Fig. 2: Soil Profile of Site -B

Table 3: Geotechnical Properties of Soil Collected from Site-B at varying depth

\begin{tabular}{|c|c|c|c|c|c|}
\hline $\begin{array}{c}\text { Depth } \\
\text { of trial } \\
\text { pit in } \\
\text { meter }\end{array}$ & $\begin{array}{c}\text { Specific } \\
\text { Gravity }\end{array}$ & $\begin{array}{c}\text { Maximum } \\
\text { Dry density } \\
\text { in gm/ } \mathrm{cm}^{3}\end{array}$ & $\begin{array}{c}\text { Optimum } \\
\text { moisture } \\
\text { content \% }\end{array}$ & $\begin{array}{c}\text { Cohesion in } \\
\mathrm{kN} / \mathrm{m}^{2}\end{array}$ & $\begin{array}{c}\text { Angle of internal } \\
\text { friction (Ø) in } \\
\text { degrees }\end{array}$ \\
\hline 1.0 & 2.64 & 1.70 & 16.9 & 14.0 & 25.0 \\
\hline 1.5 & 2.72 & 1.86 & 10.2 & 4.0 & 37.0 \\
\hline 1.8 & 2.77 & 1.89 & 10.1 & 2.0 & 40.0 \\
\hline
\end{tabular}

From table 3 , it is found that, at a depth of $1.0 \mathrm{~m}$ coarse grained disintegrated weathered soil called soft moorum is observed. At depths of $1.5 \mathrm{~m}$ and $1.8 \mathrm{~m}$ hard moorum is observed. At $1.0 \mathrm{~m}$ depth the maximum dry density of soil is found to be $1.70 \mathrm{gm} / \mathrm{cm}^{3}$ and optimum moisture content is $16.9 \%$. At depths $1.5 \mathrm{~m}$ and $1.8 \mathrm{~m}$ the values of maximum dry density are found to be $1.86 \mathrm{gm} / \mathrm{cm}^{3}$ and $1.89 \mathrm{gm} / \mathrm{cm}^{3}$ and optimum moisture content found to be $10.2 \%$ and $10.1 \%$ respectively. The values of cohesion are found to be $4 \mathrm{kN} / \mathrm{m}^{2}$ and $2 \mathrm{kN} / \mathrm{m}^{2}$ at $1.5 \mathrm{~m}$ and $1.8 \mathrm{~m}$ depth, respectively.

\section{Results And Discussion}

The inputs required for determination of ultimate bearing capacity of soil are: cohesion, unit weight of soil, depth of proposed foundation, width of foundation and bearing capacity factors. In general, unless otherwise mentioned the width of footing is assumed to be 1.0 meter. For non-cohesive soil the value of cohesion is less and hence neglected. Most of time, this cohesion is apparent cohesion. For this soil by using IS code method, the values of ultimate bearing capacity and safe bearing capacities are determined.

Procedure laid down by Bureau of Indian Standard IS: 6403-1981 is used for calculating ultimate net bearing capacity. Equation (1) is used for determination of net ultimate bearing capacity of soil for general shear failure case.

$$
q d=c ~ N c+q(N q-1)+0.5 \square B ~ N
$$

Similarly equation (2) is used for determination of net ultimate bearing capacity of soil for local shear failure case.

$$
\mathrm{qd}=\square \mathrm{cN} \mathrm{N}^{\prime}+\mathrm{q}\left(\mathrm{N}^{\prime} \mathrm{q}-1\right)+0.5 \square \mathrm{B} \mathbf{N}^{\prime}
$$

Where $\mathrm{Nc}, \mathrm{Nq}$, and $\mathrm{N}_{\square}$ are bearing capacity factors for general shear failure case, $\mathrm{N}^{\prime} \mathrm{c}, \mathrm{N}^{\prime} \mathrm{q}$, and $\mathrm{N}^{\prime}$ are bearing capacity factors for local shear failure, $\mathrm{c}$ is cohesion, $\mathrm{B}$ is width of footing and $\mathrm{q}$ is surcharge of soil mass.

\subsection{Effect of Depth of Footing on Ultimate Bearing Capacity and Safe Bearing Capacity}

The depth of footing is important parameter which governs the ultimate bearing capacity of the soil. For site-A, the effect of depth of rectangular footing on ultimate bearing capacity and safe capacity of soil is studied. Length of footing at site-A assumed to be 1.5 times the width of footing. The values of ultimate bearing capacities and safe bearing capacities determined for different sites by IS code method are as shown in table 4 . 
Investigation Of Soil And Bearing Capacity In Different Site Conditions

Table 4: Effect of Depth of Rectangular Footing on Ultimate and Safe Bearing Capacity

\begin{tabular}{|c|c|c|c|c|c|}
\hline Site $-\mathrm{A}$ & \multicolumn{4}{|c|}{ Waste disposal site cantonment land Survey.No.207/1, Aurangabad } \\
\hline $\begin{array}{c}\text { Depth of footing in } \\
\text { meter }\end{array}$ & 1.0 & 1.5 & 2.0 & 2.5 & 3.0 \\
\hline $\begin{array}{c}\text { Ultimate bearing } \\
\text { capacity }\left(\mathrm{kN} / \mathrm{m}^{2}\right)\end{array}$ & 229.35 & 319.9 & 516.70 & 637.58 & 869.13 \\
\hline Type of Failure & $\begin{array}{c}\text { Local shear } \\
\text { failure }\end{array}$ & $\begin{array}{c}\text { Local shear } \\
\text { failure }\end{array}$ & $\begin{array}{c}\text { General } \\
\text { shear } \\
\text { failure }\end{array}$ & $\begin{array}{c}\text { General } \\
\text { shear } \\
\text { failure }\end{array}$ & $\begin{array}{c}\text { General } \\
\text { shear } \\
\text { failure }\end{array}$ \\
\hline $\begin{array}{c}\text { Safe bearing capacity } \\
\left(\mathrm{kN} / \mathrm{m}^{2}\right)\end{array}$ & 85.93 & 122.81 & 194.73 & 241.29 & 325.61 \\
\hline
\end{tabular}

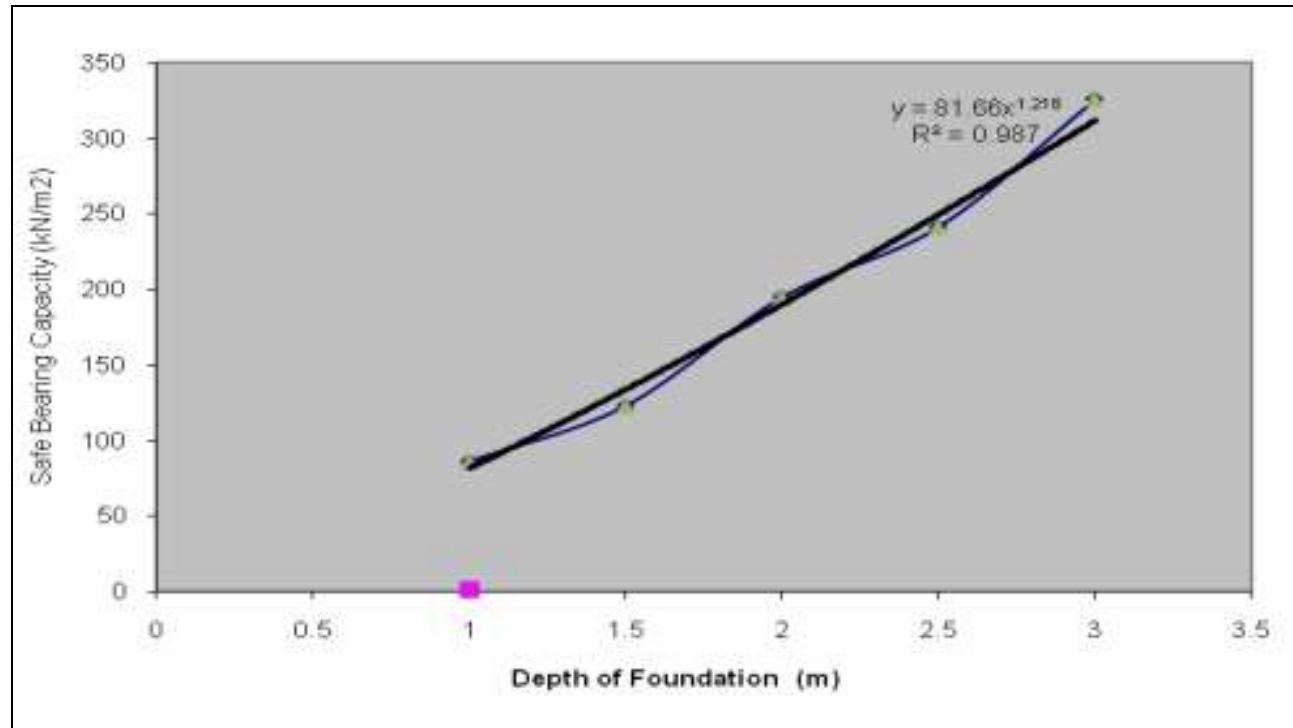

Fig.3: Graphical representation of Safe Bearing Capacity Versus Depth of Foundation

Fig. 3 shows the graphical representation of depth of foundation versus safe bearing capacity for site-A. The correlation developed between depth of foundation and safe bearing capacity is as given by equation (3)

$$
\mathbf{y}=81.66 x^{1.218}
$$

Where $\mathrm{y}=$ Safe bearing capacity in $\mathrm{kN} / \mathrm{m}^{2} ; \mathrm{x}=$ Depth of foundation in meter.

From the equation (3) the value of safe bearing capacity for depth of foundation in the range of $1.0 \mathrm{~m}$ to $3.0 \mathrm{~m}$ can be found out and used for design.

At site-A the values of angle of internal friction $(\varnothing)$ are 18, 27, 33, 34 and 36 degrees, for depth 1, 1.5, 2, 2.5 and 3 meters respectively. The value of safe bearing capacity of the soil at $1.5 \mathrm{~m}$ depth is $42.91 \%$ higher than $1.0 \mathrm{~m}$ depth and for further increase in depth the safe bearing capacity increases considerably. It is also found that as depth of foundation increases the cohesion (c) decreases and angle of internal friction increases. The effect of increase in depth on increase in safe bearing capacity is predominant due to increase in surcharge weight, which governs the safe bearing capacity of the soil. Similarly if type of failure is general shear failure for the same value of $\varnothing$ the values of bearing capacity factors $\mathrm{Nc}, \mathrm{Nq}$, and $\mathrm{N}_{\square}$ are very high in comparison with $\mathrm{N}^{\prime} \mathrm{c}, \mathrm{N}^{\prime} \mathrm{q}$, and $\mathrm{N}^{\prime}$. Here at 1.0 and $1.5 \mathrm{~m}$ depth the failure is local shear failure and after $1.5 \mathrm{~m}$ the failure changes to general shear failure. Hence, the values of safe bearing capacities from 2 to $3 \mathrm{~m}$ depth increases appreciably. In general, it is understood that with other factors remaining constant as depth of foundation increases the bearing capacity of soil increases. Based on judicious judgment, at site-A design depth of foundation can be suggested as 2.0 meter.

At site- $\mathrm{B}$, it is found that the soil is c- $\square$ soilup to $1.15 \mathrm{~m}$ depth and beyond $1.15 \mathrm{~m}$ depth a non cohesive coarse grained soil is observed. The values of angle of internal friction of soil particles $(\varnothing)$ are found to be $25^{\circ}$, $37^{\circ}$ and $40^{\circ}$ at $1 \mathrm{~m}, 1.5 \mathrm{~m}$ and $1.8 \mathrm{~m}$ depth respectively. For site-B, by considering rectangular footing the values of ultimate, net and safe bearing capacity are determined. At $1.0 \mathrm{~m}$ depth local shear failure is assumed and for $1.5 \mathrm{~m}$ and $1.8 \mathrm{~m}$ depth general shear failure is assumed. The values are tabulated as shown in table 5 . The values 
of ultimate, net and safe bearing capacities are determined for this site at $1 \mathrm{~m}, 1.5 \mathrm{~m}$ and $1.8 \mathrm{~m}$ depth assuming factor of safety of 3 by using IS code method.

Table 5: Ultimate Bearing Capacity and Safe Bearing Capacity for Rectangular Footing

\begin{tabular}{|c|c|c|c|}
\hline \multicolumn{1}{|c|}{ Site -B } & \multicolumn{3}{|c|}{ Behind weekly market } \\
\hline Depth of footing in meter & 1.0 & 1.5 & 1.8 \\
\hline $\begin{array}{l}\text { Ultimate bearing } \\
\text { capacity }\left(\mathrm{kN} / \mathrm{m}^{2}\right)\end{array}$ & 249.21 & $2025.74(712.86)$ & $3342.45(1241.21)$ \\
\hline Net bearing capacity $\left(\mathrm{KN} / \mathrm{m}^{2}\right)$ & 232.54 & $1998.38(759.37)$ & $3509.08(1409.02)$ \\
\hline Safe bearing capacity $\left(\mathrm{kN} / \mathrm{m}^{2}\right)$ & 94.18 & $693.48(636.33)$ & $1136.40(1106.62)$ \\
\hline Type of Failure & $\begin{array}{c}\text { Local shear } \\
\text { failure }\end{array}$ & $\begin{array}{c}\text { General shear } \\
\text { failure }\end{array}$ & $\begin{array}{c}\text { General shear } \\
\text { failure }\end{array}$ \\
\hline
\end{tabular}

Table 5 shows the values of ultimate, net and safe bearing capacity at a depth of $1 \mathrm{~m}, 1.5 \mathrm{~m}$ and $1.8 \mathrm{~m}$. The safe bearing capacity at $1.0 \mathrm{~m}$ depth is found to be $94.81 \mathrm{kN} / \mathrm{m}^{2}$. In comparison with $1.0 \mathrm{~m}$ depth of foundation the values of safe bearing capacity at depth of $1.5 \mathrm{~m}$ and $1.8 \mathrm{~m}$ are found to be $636.33 \%$ and $1106.62 \%$ higher respectively. This higher percentage of safe bearing capacity for $1.5 \mathrm{~m}$ and $1.8 \mathrm{~m}$ depth is observed due to higher value of angle of internal friction of soil and general shear failure at $1.5 \mathrm{~m}$ and $1.8 \mathrm{~m}$ depth. So at site-B i.e. proposed construction of "School building" for Cantonment Board Office at Aurangabad, it is suggested that the depth of foundation shall be taken as $1.8 \mathrm{~m}$.

\subsection{Effect of Shape of Footing on Ultimate Bearing Capacity}

The shape of footing influences the bearing capacity. Terzaghi and other contributors have suggested the correction to the bearing capacity equation for shapes of different footing based on their experimental findings. Table 6 shows the values of ultimate bearing capacities determined for different shapes for site-A by IS code method. Table 6 indicates the values of ultimate bearing capacity for different depth of foundation i.e. $1.0 \mathrm{~m}, 1.5 \mathrm{~m}, 2.0 \mathrm{~m}, 2.5 \mathrm{~m}$ and $3.0 \mathrm{~m}$ for different shapes of footing i.e. strip, square, circular and rectangular footing by IS code method. At $1.0 \mathrm{~m}$ and $1.5 \mathrm{~m}$ depth local shear failure is assumed and for $2.0 \mathrm{~m}, 2.5 \mathrm{~m}$, and $3.0 \mathrm{~m}$ depth general shear failure is assumed. Amongst the different shapes of footing by remaining other factors constant for square shaped footing the values of ultimate bearing capacity are found to be higher and least values are observed for strip footing. Similarly if comparison is made between circular and rectangular shapes footings the ultimate bearing capacity are higher for circular shape. The percentage increase in ultimate bearing capacity for square shape of the footing in comparison with strip footing at $1.0 \mathrm{~m}, 1.5 \mathrm{~m}, 2.0 \mathrm{~m}, 2.5 \mathrm{~m}$ and $3.0 \mathrm{~m}$ depth of foundation for site-A is found to be $24.86 \%, 19.03 \%, 14.09 \%, 13.80 \%$ and $13.36 \%$ respectively. The percentage increase of the order of $24.86 \%$ is found to be for lesser depth of foundation i.e. $1 \mathrm{~m}$ and $13.36 \%$ is observed for $3.0 \mathrm{~m}$ depth of foundation.

Table 6: Effect of Shape of Footing on Ultimate Bearing Capacity in $\mathrm{kN} / \mathrm{m}^{2}$ for Site-A

\begin{tabular}{|l|c|c|c|c|c|}
\hline \multirow{2}{*}{ Shape of footing } & \multicolumn{5}{|c|}{ Depth of footing in meters } \\
\cline { 2 - 6 } & 1.0 & 1.5 & 2.0 & 2.5 & 3.0 \\
\hline Strip & 206.80 & 295.35 & 1486.26 & 1877.69 & 2740.70 \\
\hline Square & 258.22 & 351.55 & 1695.70 & 2136.77 & 3106.92 \\
& $(24.86)$ & $(19.03)$ & $(14.09)$ & $(13.80)$ & $(13.36)$ \\
\hline Circular & 255.71 & 344.14 & 1636.34 & 2065.90 & 3005.84 \\
\hline Rectangular & 229.35 & 319.90 & 1565.70 & 1986.30 & 2903.97 \\
\hline Type of failure & $\begin{array}{c}\text { Local Shear } \\
\text { Failure }\end{array}$ & $\begin{array}{c}\text { Local Shear } \\
\text { Failure }\end{array}$ & $\begin{array}{c}\text { General } \\
\text { Shear Failure }\end{array}$ & $\begin{array}{c}\text { General } \\
\text { Shear Failure }\end{array}$ & $\begin{array}{c}\text { General } \\
\text { Shear Failure }\end{array}$ \\
\hline
\end{tabular}




\subsection{Effect of Water Table on Bearing Capacity}

The change in moisture content of the soil affects the properties of the soil. Similarly, if soil gets submerged its ability to support the load coming over its unit area is reduced. When the water table is above the base of the footing, the submerged weight is used for the soil below the water table for computing the surcharge. The water table corrections are applied to determine the ultimate bearing capacity of the soil. When water reaches up to ground level, here the unit weight of soil considered in presence of water table is submerged density and, hence the reduction coefficients $\mathrm{Rw}_{1}$ and $\mathrm{Rw}_{2}$ are used in second and third terms of bearing capacity equation to consider the effects of water table. The effect of water table correction on safe bearing capacity is predominant for non-cohesive soil.

At site-B for depth of foundation greater than $1.5 \mathrm{~m}$ depth soil is found to be non- cohesive in nature and hence general shear failure is assumed. The shape of footing is assumed to be square and by applying water table correction and by using factor of safety equal to 3 and by keeping other parameters constant the values of safe bearing capacities determined by IS code method are as shown in table 7. In table 7 the values in parenthesis indicate percentage decrease in safe bearing capacity of soil in comparison with no water table correction.

Table 7: Effect of water table on safe bearing capacity of soil at Site - B for square footing

\begin{tabular}{|c|c|c|c|c|}
\hline \multirow{2}{*}{$\begin{array}{c}\text { Depth } \\
\text { of } \\
\begin{array}{c}\text { Footing } \\
\text { in } \mathrm{m}\end{array}\end{array}$} & $\begin{array}{c}\text { Without water } \\
\text { table correction }\end{array}$ & $\begin{array}{c}\text { Water table may } \\
\text { reach up to the base } \\
\text { of the footing }\end{array}$ & $\begin{array}{c}\text { Water table may } \\
\text { reach up to the } \\
\text { ground level }\end{array}$ & \multirow{2}{*}{ Type of failure } \\
\hline 1.0 & 232.09 & $220.0(5.20)$ & $184.45(25.52)$ & Local shear failure \\
\hline 1.5 & 745.35 & $664.87(10.79)$ & $430.01 \quad(42.30)$ & General shear failure \\
\hline 1.8 & 1214.91 & $1079.68(11.13)$ & $651.22(46.39)$ & General shear failure \\
\hline
\end{tabular}

From table 7, it is found that for soil from site-B at $1 \mathrm{~m}$ depth the value of $\varnothing$ equal to $25^{\circ}$, the percentage decrease in safe bearing capacity due to water table correction is found to be $5.20 \%$ and $25.52 \%$ with water table may reach up to the base of the footing and up to ground level respectively. At $1.5 \mathrm{~m}$ depth the value of $\varnothing$ equal to $37^{0}$ the percentage decrease in safe bearing capacity due to water table correction is found to be $10.79 \%$ and $42.30 \%$ with water table may reach up to the base of the footing and up to ground level respectively. Similarly, at $1.8 \mathrm{~m}$ depth the value of $\varnothing$ equal to $40^{\circ}$ the percentage decrease in safe bearing capacity due to water table correction is found to be $11.13 \%$ and $46.39 \%$ with water table may reach up to the base of the footing and up to ground level respectively.

Similarly the effect of water table on safe bearing capacity of soil for rectangular footing is studied by keeping other parameters constant. In table 8 , the values in parenthesis indicate percentage decrease in safe bearing capacity of soil in comparison with no water table correction.

Table 8: Effect of water table on safe bearing capacity of soil at Site -B for rectangular footing

\begin{tabular}{|c|c|c|c|c|}
\hline \multirow{2}{*}{$\begin{array}{l}\text { Depth of } \\
\text { Footing } \\
\text { in meter }\end{array}$} & \multicolumn{3}{|c|}{ Safe bearing capacity in $\mathrm{kN} / \mathrm{m}^{2}$} & \multirow[t]{2}{*}{ Type of failure } \\
\hline & $\begin{array}{c}\text { Without water } \\
\text { table } \\
\text { correction }\end{array}$ & $\begin{array}{l}\text { Water table may } \\
\text { reach up to the } \\
\text { base of the footing }\end{array}$ & $\begin{array}{l}\text { Water table may } \\
\text { reach up to the } \\
\text { ground level }\end{array}$ & \\
\hline 1.0 & 210.01 & $198.93(5.27)$ & $165.35(21.26)$ & Local shear failure \\
\hline 1.5 & 693.49 & $619.70(10.64)$ & $397.89(42.62)$ & General shear failure \\
\hline 1.8 & 1136.40 & $1012.44(10.90)$ & $607.77(46.51)$ & General shear failure \\
\hline
\end{tabular}

From table 8 , it is observed that in case of rectangular footing at $1 \mathrm{~m}$ depth the percentage decrease is found to be $5.27 \%$ and $21.26 \%$ with water table may reach up to the base of the footing and up to ground level respectively. At $1.5 \mathrm{~m}$, the decrease in safe bearing capacity due to water table correction is found to be $10.64 \%$ and $42.62 \%$ with water table may reach up to the base of the footing and up to ground level respectively. Similarly at $1.8 \mathrm{~m}$ depth the percentage decrease is $10.90 \%$ when water reaches up to base of footing and $46.51 \%$ with water table may reach up to ground level. 


\section{Conclusions}

Based on the studies carried out following conclusions are drawn.

I. The important parameters which govern the bearing capacity of soil are: cohesion, unit weight of soil, depth of proposed foundation, width of foundation and angle of internal friction.

II. In general as depth of foundation increases ultimate bearing capacity of soil increases. The effect of increase in depth on safe bearing capacity is predominant due to increase in surcharge weight.

III. For site-A the design depth of foundation suggested is $2.0 \mathrm{~m}$ because at $2.0 \mathrm{~m}$ depth the general shear failure has been observed and value of safe bearing capacity is $194.73 \mathrm{kN} / \mathrm{m}^{2}$. Individual column footing is recommended, as suitable foundation.

IV. For site-B the design depth of foundation is suggested is $1.8 \mathrm{~m}$ and individual column footing is recommended. Here though general shear failure occurs at $1.5 \mathrm{~m}$ depth and the value of safe bearing capacity is $693.48 \mathrm{kN} / \mathrm{m}^{2}$ the design depth is suggested as $1.8 \mathrm{~m}$ because at this increasing depth the value of safe bearing capacity is $1136.40 \mathrm{kN} / \mathrm{m}^{2}$.

V. For studying the effect of shape of footing on the values of ultimate bearing capacity determined for local shear failure and general shear failure, it is found that for square shaped footings the values obtained are found to be higher than strip, circular and rectangular footings. The percentage increase in ultimate bearing capacity for square shape of the footing in comparison with strip footing at $1.0 \mathrm{~m}, 1.5 \mathrm{~m}, 2.0 \mathrm{~m}$, $2.5 \mathrm{~m}$ and $3.0 \mathrm{~m}$ depth of foundation for site-A are found to be $24.86 \%, 19.03 \%, 14.09 \%, 13.80 \%$ and $13.36 \%$ respectively. The percentage increase is found to be more for lesser depth of foundation in comparison with greater depth of foundation.

VI. For cohesive and frictional soil leading to local shear failure, the effect of water table correction on safe bearing capacity is less in comparison with non-cohesive soil with general shear failure assumption. Safe bearing capacity of non-cohesive soil at site-B is reduced to $42.30 \%$ and $46.39 \%$ at $1.5 \mathrm{~m}$ and $1.8 \mathrm{~m}$ depth respectively when water table may reach up to ground level.

VII. For proposed structure, if water table may reach nearer to base of footing or up to ground level necessary water table corrections must be applied for achieving the values of safe bearing capacity for design of foundation.

\section{Acknowledgement}

I am pleased to acknowledge my indebtedness to Dr. K.A.Patil my guide, for his innovative and invaluable suggestions during the work. I am thankful to him for his gracious encouragement, pursuance for completion of this work and very valued constructive guidance in reviewing the laboratory results of this work. I offer profound gratitude towards Dr. U. J. Kahalekar, Head of Civil Engineering Department Government College of Engineering Aurangabad for providing me all the excellent academic facilities required to complete this work. I am very much thankful to Shri. M.S.Dixit for the help extended by him during course of this work. I am thankful to the soil laboratory Assistant and staff member's of Central Library, Government College of Engineering Aurangabad and to all my friends who have extended me co-operation during completion of this work.

\section{References}

[1] Bohdan Zadroga 1994, 'Bearing capacity of shallow foundations on non-cohesive soil', ASCE, Journal of Geotechnical Engineering, vol.120, no.11, November 1994, pp 1991-2008.

[2] Griffths D.V., Fenton G.A. and Manoharan N 2002, 'Bearing capacity of rough rigid strip footings on cohesive soil: Probabilistic Study', 'Journal of Geotechnical and Geo-environmental Engineering', ASCE, September 2002, pp 743-755.

[3] Hans L Erickson and Andrew Drescher 2002, 'Bearing capacity of circular footings', 'Journal of Geotechnical and Geoenvironmental Engineering', ASCE, vol. 128, no.1, January 2002, pp 38-43.

[4] Junhawan Lee and Rodrige Salgado 2005, 'Estimation of bearing capacity of circular footings on sands based on cone penetration test' 'Journal of Geotechnical and Geo-environmental Engineering', ASCE, April 2005, pp 442-452.

[5] Richard P. Weber 2008, "Bearing capacity of shallow footings for Non-geotechnical engineers", Journal of Geotechnical Engineering, study material, pp 1-8.

[6] Kasmalkar B.J. 2002, 'Foundation Engineering' Pune Vidyarthi Griha Prakashan, Sadashiv peth, Pune

[7] Nayak N. V. 2001, 'Foundation design manual' Dhanpat Rai Publications Private Limited, New Delhi.

[8] Punmiya B. C. 2003, 'Soil Mechanics and Foundation' Laxmi Publications Private Limited, New Delhi.

[9] Indian Standard "IS: 6403-1981 Code of practice for determination of bearing capacity of shallow foundations", (First revision). 